Regards sur l'économie allemande

Bulletin économique du CIRAC

$111 \mid 2013$

Varia

\title{
Praxis politique
}

ECKERT Georg, NOVY Leonard, SCHWICKERT Dominic (eds), Zwischen Macht und Ohnmacht. Facetten erfolgreicher Politik

\section{CpenEdition}

\section{Journals}

Édition électronique

URL : http://journals.openedition.org/rea/4638

DOI : $10.4000 /$ rea.4638

ISSN : 1965-0787

Éditeur

CIRAC

\section{Édition imprimée}

Date de publication : 1 décembre 2013

Pagination : 40

ISSN : 1156-8992

Référence électronique

«Praxis politique », Regards sur l'économie allemande [En ligne], 111 | décembre 2013, mis en ligne le 17 décembre 2013, consulté le 22 septembre 2020. URL : http://journals.openedition.org/rea/4638 ; DOI : https://doi.org/10.4000/rea.4638

Ce document a été généré automatiquement le 22 septembre 2020

(C) CIRAC 


\section{Praxis politique}

ECKERT Georg, NOVY Leonard, SCHWICKERT Dominic (eds), Zwischen Macht und Ohnmacht. Facetten erfolgreicher Politik

\section{RÉFÉRENCE}

ECKERT Georg, NOVY Leonard, SCHWICKERT Dominic (eds), Zwischen Macht und Ohnmacht. Facetten erfolgreicher Politik, Springer Fachmedien, Wiesbaden, 2013, $432 \mathrm{p}$.

1 Qu'est-ce qui fait qu'une politique est couronnée de succès et quels sont les obstacles rencontrés ? Comment répondre aux apirations des électeurs sans pour autant en devenir prisonnier et perdre de vue l'intérêt général ? Quel est le sain dosage entre communication politique et dialogue citoyen? Voilà les questions au cœur de cet ouvrage collectif édité par des professeurs de sciences politiques, toutes obédiences confondues. Il fourmille de témoignages et analyses d'éminents responsables politiques allemands - chefs de gouvernement d'un Land, ministres fédéraux, députés, issus de tous les grands partis. Ce qu'on en retient? 'Faire de la politique' est un véritable métier qui, comme tout métier, demande l'acquisition d'un savoir-faire pratique et théorique et, avant tout, d'un savoir-être. (ib) 